\title{
Review
}

\section{Possibilities and limitations of weed management in fruit crops of the temperate climate zone}

\author{
Jerzy Lisek*
}

Research Institute of Horticulture, Konstytucji 3 Maja 1/3, 96-100 Skierniewice, Poland

Received: August 14, 2014

Accepted: October 19, 2014

\begin{abstract}
This manuscript contains information on the species composition of weed communities in orchards in Poland and other countries of the temperate climate zone. The manuscript deals with the influence of weeds on crops and the interaction between the weeds and other living organisms. The main methods of weed regulation are described. Characteristics of the particular crops - fruit trees and small fruits - and solutions that are either objects of study or have already been introduced into practice, are presented. Advantages and disadvantages of different methods of weed control are discussed, such as soil cultivation and tillage, cover crops, mulches, herbicide use, and flame burning.
\end{abstract}

Key words: cover crops, herbicides, mulches, orchard, small fruit plantations, soil cultivation, weeds

\section{Introduction}

In Poland, fruit crops cover an area of around 450,000 ha. Poland is one of the main world suppliers of temperate climate zone fruit: apples, high blueberries, raspberries, blackcurrants, and chokeberries. Because of the diversification of fruit crop biology and cultivation technologies, weed control in orchards, strawberry fields, and for fruit bushes has a specific character. Persistent (fruit trees and high blueberry bushes are exploited for 15-50 years, raspberry, currant, and gooseberry for 8-15 years, and strawberry up to four years) problems with the mechanisation of soil cultivation in densely planted rows and insufficient rotation of the control methods, all favour weed compensation. The first aim of the work is to present major threats to fruit production which are the result of weed infestation. The second aim is to present the current state of integrated protection of orchards and fruit agricultural fields against weeds in Poland and other countries which have a temperate climate zone.

\section{Weed species and their harmful effects on fruit crops}

Species composition of weeds depends on environmental conditions (chiefly the climate and soil properties), cultivation techniques, and fertilisation. In Polish orchards and farm fields, where the main method of weed control is the use of herbicides, there are around 30 species of frequently occurring segetal and ruderal weeds. Annual weeds are common: Stellaria media (L.) Vill., Chenopodium album L., Senecio vulgaris L., Capsella bursa-pastoris (L.) Med., Gera- nium pusillum Burm. F. ex L., Lamium purpureum L., Viola arvensis Murr., Conyza canadensis (L.) Cronq., Polygonum aviculare L., Polygonum persicaria L., Fallopia convolvulus (L.) A. Löve, Galium aparine L., Amaranthus retroflexus L., Galinsoga parviflora Cav., Urtica urens L., Veronica persica Poir., Matricaria maritima L. ssp. inodora (L.), Chamomilla suaveolens (Pursh) Rydb., Echinochloa crus-galli (L.) P. Beauv., Setaria pumila (Poir.) Roem et Schult., Poa annua L. Perennial weeds include: Taraxacum officinale F. H. Wigg., Epilobium adenocaulon Hausskn., Cirsium arvense (L.) Scop., Equisetum arvense L., Convolvulus arvensis L., Rorippa sylvestris (L.) Besser, Artemisia vulgaris L., Rumex acetosella L., and Agropyron repens L. [Elytrigia repens (L.) Desv. ex Nevski] (Wróbel 1999; Lipecki 2004; Lisek 2012b, c). Weeds such as S. media, C. bursa-pastoris or G. pusillum, which are typical of the regional orchards where herbicides are applied, did not occur in the flora of young organic orchards in Skierniewice (Central Poland). These weeds consist of 25 species (Mika 2004). These annuals did not have a chance to establish due to compost mulching or soil cultivation and competition from other species such as Polygonum hydropiper L., A. retroflexus, and S. pumila.

Some species like $C$. arvensis are cosmopolitan plants and occur as weeds in the orchards of various countries: Argentina (Conticello and Gandullo 1991), Bulgaria (Tasseva 2005) and Turkey (Ustuner and Ustuner 2011). Ch. album is an example of a cosmopolitan one-year weed, frequently occurring in the orchards of South Korea (Jung et al. 1997), Argentina (Novo et al. 2000), New Zealand (Harrington et al. 2002), Canada (Rifai et al. 2002), Bulgaria (Tasseva 2005), and Turkey (Ustuner and Ustuner 
2011). According to the previously cited authors, S. media, C. bursa-pastoris, E. crus-galli, and P. aviculare belong to the group of species commonly occurring in the orchards of different countries and continents. This means that the anthropogenic factor - the orchard floor management has a significant influence on the species composition of orchard synanthropic flora, including weeds. Although rarely occurring in orchards, the following are frequently found in the fields of high blueberry: Spergula arvensis L., Spergularia rubra (L.) J. Pres et C. Presl., Viola tricolor L., Polygonum lapathifolium L., Polygonum amphibium L. var. terrestre, Vicia cracca L., Chamaenerion angustifolium (L.) Scop., Agrostis gigantea Roth and Calamagrostis epigejos (L.) Roth (Lisek 2012c).

The negative influence of weeds on fruit crops is a complex issue. Competition exists for water, nutrients, and light. There is allelopathy to be taken into consideration (Zimdahl 1980; Lipecki 2006) as well as conditions that favour the proliferation of rodents (Byers 1984), pests (Łęski 1983), fungi, and virus diseases (Jones and Sutton 1996). Weeds can also stimulate the freezing of flowers during spring frosts (Futch 2000). Weeds make it difficult or impossible to use a fruit harvester to harvest fruit from bushes (Cianciara 1987). The presence of honey weeds blooming during the period of intensive chemical used in orchards and farm fields, may poison bees and other pollinators due to the chemical residues of plant protection products on the weeds (Anderson and Glova 1984).

A precise determination of critical periods, and weed injury levels, is difficult due to the biology of the trees and the great number and changeability of factors. Weed harmfulness - and consequently the date of treatment and the number of weeds that need to be treated - are modified by: the cultivar (including the rootstock), the age and condition of trees, type and richness of soil, and species composition of weeds. The development phase of both weeds and trees and the course of weather conditions, mainly the amount of precipitation, also play a part. In the case of trees which are perennial crops, the harmful effects of weeds have been observed to be shifted to the next vegetative period (Al-Hinai and Roper 2001). Weeds might be one of the factors that cause alternate bearing (Gut et al. 1996). Pome trees are particularly susceptible to weed competition during spring and the first half of summer, from April to the end of July in the northern hemisphere (Gut et al. 1996; Merwin 2003). The situation is similar in the case of currants. The critical period lasts from the beginning of vegetation until the shoots stop growing (Rhodes 1984). Stone trees require effective weed control from April to September (Al-Hinai and Roper 2001). Raspberry is susceptible to weed competition in spring, between May and July, and should be free from weeds in June when primo-canes are developing (Lawson and Wiseman 1976a). Blueberry, due to the lack of root hair, is susceptible to weed competition throughout the whole vegetative period, until October, with greatest attention being paid to weed control from April to August (Caroll et al. 2012). Weed competition is oppressive to strawberry from April to June (Lawson and Wiseman 1976b; Pritts and Kelly 2001). In strawberry fields planted in spring (March-April), the first weed control treatment should take place no later than between the fourth and the eighth week after the crops have been planted (Lisek 2010). July and August are also considered to be critical periods for strawberry. This period is when weed competition has a cumulative character. Losses increase when weeds grow in consecutive critical periods, but too frequent soil cultivation or the use of herbicides have a negative impact on the growth and yielding of strawberry. In well-maintained, fruitful fields, it is sufficient to conduct a thorough weed control treatment 2-3 times per season (Pritts and Kelly 2004).

Synanthropic flora can also be beneficial. It constitutes a significant part of the landscape. Synanthropic flora has an influence on many living organisms: soil bacteria, arbuscular mycorrhizal fungi, annelida worms, arthropod fauna and vertebrate, co-determining the biological diversity (Kennedy and Smith 1995; Wyss 1996; Burrows and Pfleger 2002; Storkey and Westbury 2007). This type of flora improves the chemical and physical properties of the soil. These properties include organic matter content, porosity and water holding capacity, protection of the soil against erosion (deterioration caused by water and wind) during winter dormancy of the fruit trees, accumulation of nutrients in the green biomass preventing leaching. Snow is kept within the orchard which increases the reserve of moisture in the soil and limits the frost damage to tree roots (Lipecki 2006).

\section{Main methods of orchard floor management and integrated weed control}

Contemporary orchard floor management combines soil cultivation and tillage, cover crops, mowing of weeds and cover plants, mulches and herbicide use, and a relatively new method - flame burning of weeds. The solution for the typical Polish orchards is to maintain grassed alleyways and herbicide fallow under the tree canopies. The width of the herbicide strip is $0.6-2.0 \mathrm{~m}$. This model is effective and creates conditions that favour tree growth and machine work in the orchard. Herbicides are effective, easily executed, relatively cheap, and ensure high yielding of trees (Harrington et al. 2005). Fruit tree roots grow better in herbicide fallow than mechanical fallow or under cover plants (Parker et al. 1993). Recently, the small number of herbicides registered for use in orchards and berry fields has been a growing problem. Polish producers can use nine herbicides: soil acting - pronamide and post-emergence - glyphosate, propachizafop, quizalofop-p-ethyl (bushes and orchards); MCPA, 2,4-D, fluroxypyr (orchards); clopyralid and glufosinate-ammonium (fruit bushes) (Lisek 2014). The overuse of glyphosate leads to: phytotoxicity, the presence of its residue in the environment (Heinonen-Tanski et al. 1985; Giesey et al. 2000; Humphries et al. 2005) and crops (Roy et al. 1989), proliferation of uncontrolled weeds such as E. adenocaulon, R. sylvestris (Lipecki 2004; Lisek 2012c), and selection of weed biotypes resistant to herbicides (Peachey et al. 2013). In the years 1996-2013, 29 weed species were observed to create biotypes resistant to glyphosate (WeedScience 2014). Resistant forms of C. canadensis were observed in 
Poland (Adamczewski et al. 2011). Glyphosate, its metabolites and adjuvants which are included in the herbicide, mainly polyethoxylated tallowamin, have endocrine and toxic effects on mammals (Richard et al. 2005). Glyphosate phytotoxicity is a result of a typical herbicide effect after incorrect use - inhibition of shikimic acid pathway and cytochrome P450 modulation (Lamb et al. 1998; Schonbrunn et al. 2001). Glyphosate phytotoxicity has a negative impact on the rhizosphere of the crops and reduces the availability or uptake of essential macro- and micro-elements (Neumann et al. 2006; Zobiole et al. 2010). Doses of the glyphosate used in the orchards might be limited by combining the use of glyphosate with adjuvants (Lisek 2012a). The reduction in the number of glyphosate treatments to 1-2 per year and the restoration of the rotation of other herbicides requires registration of those herbicides, and a number of active substances may be taken into account. In the USA, 14 pre-emergence herbicides (dichlobenil, diuron, halosulfuron-methyl, flumioxazin, indaziflam, napropamide, norflurazon, oryzalin, oxyfluorfen, pendimethalin, pronamide, saflufenacil, and simazine, terbacil), and 8 post-emergence herbicides (carfentrazone, clethodim, clopyralid, glufosinate-ammonium, glyphosate, paraquat, pyraflufen-ethyl, rimsulfuron) have been allowed to be used in the orchards (Buckelew 2009; Lehnert 2012). After regular, multi-year use of preemergent herbicides, the amount of soil organic matter, and the density of fungi and bacteria populations were all less than in the orchard sites which were under cover crops (Tworkosky and Welker 1996; Tworkoski and Miller 2001). For this reason, pre-emergent herbicides should be used with special care. These herbicides should be used in narrower herbicide strips, and in conjunction with herbicides such as glyphosate.

To improve the effectiveness and safety of chemical weed control methods, there has been ongoing research into natural (organic) herbicides. Pelargonic acid, acetic acid (vinegar), citric acid, citrus acid (d-limonene), octanoic acid, clove oil (eugenol), cinnamon oil, lemongrass oil, and iron chelate are all regarded as natural (organic) herbicides (Dayan et al. 2009; Quarles 2010; Patton and Weisenberger 2012). The enumerated herbicides have limited effects and are used on weed seedlings.

Repeated treatments are required which entails high costs (Rowley et al. 2011). Pelargonic acid may be used together with glyphosate, which lessens the drawbacks of both products (Wehtje et al. 2009). Corn gluten meal (Christians 1995), corn gluten hydrolysate, and white mustard seed meal (Yu and Morishita 2014) are considered biologically active allelochemicals with a preemergent herbicidal effect. The bacteria Streptomyces acidiscabies Lambert et Loria might be used as a microbial herbicide against grass and broadleaf weeds (Quarles 2010). Pseudomonas fluorescens (Flügge) Migula might be used against Setaria viridis (L.) P. Beauv. (Caldwell et al. 2012). Pathogenic fungi, Phoma macrostoma Montagne (among others) might be used against T. officinale, S. media, Matricaria perforata Mérat (Graupner et al. 2006; Bailey et al. 2010). Sclerotinia minor Jagger. might be used against C. arvense, T. officinale, and others (Abu-Dieyeh and Watson 2007). The disadvantage of microbials is that there are problems with their commercialisation, expense, instability in the environment, generally narrow host range, and their unreliable effect connected with favourable environmental conditions (Hallett 2005).

Cover plants are most often maintained in orchard alleyways. Such plants: provide shelter to beneficial organisms, proper traction properties of the orchard floor, limit the kneading of the soil, and provide nutrients (Doran et al. 1998; Sanchez et al. 2003). Cover plants prevent the soil from losing nitrogen. Plants from the family Fabaceae possess the ability to fix nitrogen loss (den Hollander et al. 2007). Sodgrass in the alleyways is usually set up between the first year (fertile soil, hilly land) and the third year after the trees have been planted. Cover crops are called "living mulches" (Shribbs and Skroch 1986a, b; Hartley et al. 2000). The presence of cover crops (from the moment the cover crops are planted) in the rows of a young orchard or on the whole surface of the orchard (Neilsen and Hogue 2000) might impair the growth and yielding of trees. Cover crops, like some of the mulches, increase Phytophthora cactorum (Lebert et Cohn) Schröt. infestation and root damage caused by rodents, more than the test plots treated with herbicides (Merwin et al. 1992; Merwin et al. 1999; Wiman et al. 2009). Popular cover crops in Poland are: creeping red fescue - Festuca rubra L., Kentucky blue grass (smooth meadow-grass) - Poa pratensis L., and the perennial ryegrass - Lolium perenne L. Different kinds of grass are also sown as combinations of $2-3$ species, sometimes with the addition of white clover - Trifolium repens L. Many other species of perennial and one-year cover crops (sown in spring and autumn) are used in both tests and practice. Most of them come from the families Fabaceae and Poaceae: Persian clover - Trifolium resupinatum L., subterranean clover - T. subterraneum L., berseem clover - T. alexandrinum L., medick - Medicago sp. (Sanchez et al. 2003; TerAvest et al. 2010), bird's foot trefoil - Lotus corniculatus L. (TerAvest et al. 2010), common vetch - Vicia sativa L., pea - Pisum sativum L. (Bugg et al. 1996), white lupine - Lupinus albus L. (Walsh et al. 1996), crown vetch - Coronilla varia L. (Merwin et al. 1992, 1994, 1999, Merwin and Stiles 1994; Sanchez et al. 2003), common serradella Ornithopus sativus Brot. (Sosna et al. 2009), blue (sheep's) fescue - Festuca ovina L. (Sosna et al. 2009), hard fescue F. longifolia Thuill. (Sanchez et al. 2003), tall fescue - F. arundinacea Schreb. (Tworkoski et al. 1997), annual ryegrass - Lolium multiflorum Lam. (Sanchez et al. 2003), colonial bent grass - Agrostis vulgaris With. (Hoagland et al. 2008; Sosna et al. 2009; Wiman et al. 2009; TerAvest et al. 2010), timothy grass - Phleum pretense L. (Tworkoski and Glenn 2001), orchard grass - Dactylis glomerata L. (Neilsen and Hogue 1985; Shribbs and Skroch 1986a, b; Tworkoski et al. 1997; Tworkoski and Glenn 2001), wheat - Triticum aestivum L. (Shribbs and Skroch 1986a, b), rye - Secale cereale L. (Sanchez et al. 2003; Granatstein and Mullinix 2008), barley - Hordeum vulgare L., and oat - Avena sativa L. (Bugg et al. 1996). Beside legumes and grasses, cover crops can include Harlequin marigold - Tagetes patula nana L. (Rozpara et al. 2008), white mustard - Sinapis alba L. (Rieux 1999), tansy phacelia - Phacelia tanacetifolia Benth. (Sosna et al. 2009), and buckwheat - Fagopyrum esculentum Moench (Brown and Glenn 1999). The effectiveness of cover 
crops depends on several factors. One factor is the place of sowing, for example; alleyways, strips under trees, and the strips on both sides of tree rows. Ecological conditions, for example the species and cultivars of trees and rootstocks, also must be taken into account. The age of the orchard, and in the context of fruit trees and soil management practices, and the pruning of trees are all factors which must be considered as well (Tworkoski 2000). Crop regulations, irrigation, and nutrition also play a role (Weibel 2002; Merwin 2003; Granatstein and Sanchez 2009; Stefanelli et al. 2009). In older orchards, the trees are strong. Weakly growing weeds with limited water and nutrient needs, such as $P$. annua, can be treated as cover plants (Mika et al. 1998).

Mechanical soil cultivation is used mainly in newly established and young orchards, on the whole area or with the exclusion of strips under the tree canopies. At present, there exists the option of fully mechanising the cultivation of soil under tree canopies with the use of retracting tree rotary weeders (Rabcewicz and Białkowski 2011). Cultivation with these weeders, though, destroys the soil structure, reduces the organic matter, and causes soil erosion (Merwin et al. 1994a, b) and damage to tree roots located near the surface (Cockroft and Wallbrink 1996). The weeders are hardly effective when it comes to controlling perennial, deeply rooted weeds. Unless their work is combined with the use of herbicides, some weeds such as $A$. repens proliferate (Lisek 2012c).

Synthetic mulches can successfully control weeds in orchards. Synthetic mulches include: polyethylene plastic (Mage 1982; Camposeo and Vivaldi 2011), woven polypropylene fabric (Szewczuk and Gudarowska 2006; Markuszewski and Kopytowski 2008; Rozpara et al. 2008), nonwoven polyacrylic fabric (Camposeo and Vivaldi 2011) as well as natural mulches like grain and rape straw (Niggli et al. 1990; Varga et al. 2004; Rowley et al. 2011; Sas-Paszt et al. 2014), sawdust (Szewczuk and Gudarowska 2004; Czynczyk et al. 2011; Sas-Paszt et al. 2014), wood chips (Treder et al. 2004; Rowley et al. 2011), wood bark (Niggli et al. 1990; Szewczuk and Gudarowska 2004; Varga et al. 2004; Markuszewski and Kopytowski 2008; Rozpara et al. 2008; Sas-Paszt et al. 2014), manure (Varga et al. 2004; Sas-Paszt et al. 2014), shredded paper (Rowley et al. 2011), compost (Sas-Paszt et al. 2014), hay (Stefanelli et al. 2009), aggregated lignite (Kwiatkowska 2007), composted poultry litter (Braun and Tworkosky 2004), fruit pomace (Camposeo and Vivaldi 2011), textile (linen, jute, wool) fabric and waste (Rozpara et al. 2008; Czynczyk et al. 2011), and peat moss (Sas-Paszt et al. 2014). Straw mulch in horticultural crops may originate not only from the grain and rape mentioned above, but also from buckwheat (Kosterna 2014). Plastic and fabric are most often laid out in newly established orchards (Mage 1982; Camposeo and Vivaldi 2011). Mulches reduce weed infestation, preserve soil moisture, level soil temperature, increase the amount of soil organic matter and aeration, improve the absorption of nutrients by the trees, help uniform root distribution, and increase the microbial activity of the soil, which might improve tree growth and yield (Sanchez et al. 2003; Varga et al. 2004; Yao et al. 2005). Organic mulches do not provide sufficient protection against perennial weeds such as A. repens (Stefanelli et al. 2009). Mulches that are rich in cellulose (bark, wood dust, straw, wood chips) with a high $\mathrm{C}: \mathrm{N}$ ratio, reduce nitrogen availability (Treder et al. 2004).

The practical use of a particular weed control method is related to the implementation costs. Mulching the soil or the use of organic herbicides is several times more costly than the use of synthetic herbicides (Merwin et al. 1995; Markuszewski and Kopytowski 2008). Mulches obtained as cheap waste materials may be used locally (Rowley et al. 2011).

Since particular methods of orchard floor management used on their own, have disadvantages, the methods are often combined together. The Swiss Sandwich System (SSS) is used in organic orchards. This modified tillage system consists of a $30-50 \mathrm{~cm}$ wide strip of native spontaneous undisturbed vegetation in the centre of the tree row, two shallow tilled strips at each side of the tree row $60-90 \mathrm{~cm}$ wide, and grass sod in the alleyways (Weibel 2002; Stefanelli et al. 2009). Cultivation is done at depths of 5-10 cm with a rotary hoe cultivator, a notched disc cultivator or a spring tooth harrow when weeds are about $10 \mathrm{~cm}$ high. Cultivation is done 5-6 times in the period from April/May to August. An untillaged area encourages predatory insects to complete their life cycle. Thus, pests are limited, biodiversity is increased, soil conditions improve, and nutrient cycling is enhanced (Horton et al. 2003). The Swiss Sandwich System is easy to manage. This system reduces competition for water and nutrients, reduces threats caused by rodents, and reduces damage to trunks and roots of trees caused by machines working under the tree canopies (Stefanelli et al. 2009). Another example of integrated weed control is the use of organic herbicides in orchards mulched with organic material when the layer of mulch is violated or when weeds which have been dispersed by wind, start to germinate (Brown and Tworkosky 2006; Rowley et al. 2011).

Propane flame burning is not popular in Poland due to: the need for specialised equipment, fire risk, uselessness of this method in periods of drought, damage caused to trees, little efficiency in controlling perennial weeds and grass, and insufficiently studied effects on beneficial insects. It does, however, have its advantages. It is relatively cheap, as the costs are comparable with tillage, and it does not disturb the soil (Stefanelli et al. 2009).

\section{Weed management in small fruit crops}

Weed control in farm fields with fruit bushes is much more difficult than in orchards. It is difficult for the bushes to compete with weeds. There is no possibility of mechanised soil cultivation or the use of non-selective foliar herbicides in densely planted rows of fruit bushes. Interrows in such farm fields, like in the orchards, might be cultivated, or the interrows might be used by cover plants such as $V$. sativa, T. repens, L. perenne, F. ovina or H. vulgare (Zebarth et al. 1993; Bowen and Freyman 1995; Lindhard Pedersen 2002). Currants with grass growing in the interrows yield poorly as compared with bare fallow (Dale 2000). Yielding of raspberry on farm fields where T. repens was used as a cover plant was better than the 
yielding obtained with the use of L. perenne (Zebarth et al. 1993; Bowen and Freyman 1995). Sowing of Medicago sativa L./D. glomerata and Trifolium pratense L./P. pratense as cover crops along bush rows, reduced yielding of blackcurrant in comparison with results achieved in rows covered with bare soil (Larsson 1997). A November treatment with glyphosate can control overwintering, and hardy weeds. This treatment is safe for blackcurrant bushes which are at least three years old (Lisek 2005). Promising results for controlling the $C$. arvensis binding on blackcurrants were obtained after a post-emergence oxadiazon treatment. This treatment is selective for the already harvested currant (Cianciara 1987) or after the post-emergence bentazon treatment in May, conducted with the use of a sprayer with protective shields (Lisek 2003). Currants yield better in mulch of black plastic than in herbicide fallow (Dale 2000). The use of wood chips and black plastic does not increase the yielding of blackcurrant as much as bare soil (Larsson 1997). Raspberry growing in straw mulch yields better than on hand-weeded plots, in herbicide fallow (simazine or napropamide) or when using synthetic mulches such as black polyethylene, or whiteon-black polyethylene (Trinka and Pritts 1992).

No herbicides which control weeds in highbush blueberry farm fields were registered in Poland. In the USA and Canada, where cultivation of highbush blueberry covers a substantial area, a great number of soil and foliar herbicides have been registered, such as flumioxazin, isoxaben, oryzalin, mesotrione, napropamide, norflurazon, pronamide, clethodim, fluazifop, glufosinate, and pelargonic acid. The use these herbacides are characterised by the safety of the cultivated crops and by the high efficiency in weed control (Dittmar and Williamson 2013). Regardless of the use of herbicides in highbush blueberry farm fields, mulching the soil with pine bark, sawdust and needles improves the chemicophysical properties and is a routine treatment (Spiers 1986; Mercik and Smolarz 1995; Burkhard et al. 2009). Highbush blueberry grows and yields better in organic mulches like peat, sawdust, and woodchips. Highbush blueberry does not grow as well with black plastic and plastic woven weedmat (Albert et al. 2010; Cox et al. 2014).

In strawberry farm fields, soil cultivation is being successfully combined with the use of herbicides and mulches. In farm fields of strawberry for processing, the costs of weed control are highly significant. In these fields, the need for hand-weeding in matted-rows is reduced by the use of new cultivation tools, like the flex-tine harrow, finger weeder, and brush hoe (Kelly et al. 2007). The following herbicides have been registered for use in Polish strawberry fields: pre-emergence - lenacil, napropamide, pendimethalin; pre- and post-emergence - metamitron, ethofumesate; and post-emergence - phenmedipham, desmedipham, clethodim, fluazifop-p-butyl, propaquizafop, quizalofop-p-ethyl, clopyralid and glufosinateammonium (Lisek 2014). A mixture containing phenmedipham, desmedipham and ethofumesate (PDE) is used in a form of split application. Tolerance of strawberry cultivars to PDE is varied. The varied tolerance is probably connected to the thickness and durability of the cuticle covering the leaves (Lisek et al. 2002). Corn gluten meal and corn gluten hydrolysate with allelopatic activity are an alternative to synthetic herbicides (Nonnecke and Christians 1997; Dilley et al. 1999). Some mulches for the soil are: cereal straw, colored polyethylene plastics, polypropylene and polyacrylic spun, woolen landscaping fabric, wood bark, and sawdust. They are effective and widely used in the production of table strawberry (Forcella et al. 2003; Kęsik and Maskalaniec 2004; Johnson and Fennimore 2005). The use of biodegradable mulches from polymers and paper is inefficient due to inadequate sustainability and effectiveness (Weber 2003). Cover plants are occasionally sown in strawberry farm fields as so-called interseeded crops. The best for this purpose are spring barley and rye, sown at the end of July or in August (Cloutier and Lamarre 1997). The crops limit the growth of weeds and in the winter they reduce frost damage to strawberry. Barley dies in late autumn but remains stiff until spring. Rye requires mowing or removal in the following season. Spring rape as inter-row cover crop competes too strongly with strawberry. Spring rape, like weeds, causes a decrease in yielding (Forcella et al. 2003).

\section{Conclusions}

Weed management in fruit crops should favour primary values such as the safety of people and the environment, including the quality of soil, and should take into account the effectiveness, costs, and influence on yielding of the cultivated crops. Integrated weed control based on rational use of herbicides and alternative methods, fulfils the above requirements. Synthetic herbicides are the most effective way of controlling weeds within fruit crops. But synthetic herbicides need to be used carefully so that problems with their use can be minimised. To preserve the effectiveness and rotation, it is necessary to register a proper number of herbicides with diversified modes of action. Some of the main alternative herbicides, for example pelargonic acid, can be used positively to help with weed management. If the number of registered herbicides is small or non-existent, alternative (non-chemical) methods of weed control are indispensable.

\section{References}

Abu-Dieyeh M.H., Watson A.K. 2007. Efficacy of Sclerotinia minor for dandelion control: effect of dandelion accession, age, and grass competition. Weed Res. 47 (1): 63-72.

Adamczewski K., Kierzek R., Matysiak K. 2011. Przymiotno kanadyjskie (Conyza canadensis L.) odporne na glifosat. [Horseweed (Conyza canadensis L.) glyphosate resistant]. Prog. Plant Prot./Post. Ochr. Roślin 51 (4): 1675-1682.

Albert T., Karp K., Starast M., Paal T. 2010. The effect of mulching and pruning on the vegetative growth and yield of the halfhigh blueberry. Agronomy Res. 8 (1): 759-769.

Al-Hinai Y.K., Roper T.R. 2001. Temporal effects of chemical weed control on tart cherry tree growth, yield, and leaf nitrogen concentration. HortScience 36 (1): 80-82.

Anderson J.F., Glova W. 1984. Insecticidal poisoning of honey bees in Connecticut. Environ. Entomol. 15: 70-74.

Bailey K.L., Pitt W.M., Derby J., Walter S., Taylor W., Falk S. 2010. Efficacy of Phoma macrostoma, a bioherbicide, for control of 
dandelion (Taraxacum officinale) following simulated rainfall conditions. Am. J. Plant Sci. Biotechnol. 4 (2): 35-42.

Bowen P., Freyman S. 1995. Ground covers affect raspberry yield, photosynthesis, and nitrogen nutrition of primocanes. HortScience 30 (2): 238-241.

Brown M.W., Glenn D.M. 1999. Ground cover plants and selective insecticides as pest management tools in apple orchards. J. Econ. Entomol. 92 (4): 899-905.

Brown M.W., Tworkosky T. 2004. Pest management benefits of compost mulch on apple orchards. Agric. Ecosyst. Environ. 103 (3): 465-472.

Brown M.W., Tworkosky T. 2006. Enhancing biocontrol in orchards by increasing food web biodiversity. J. Fruit Ornam. Plant Res. 14 (3): 19-27.

Buckelew J.K. 2009. Orchard floor management in young peach [Prunus persica (L.) Batsch.]: effects of irrigation, vegetation - free with, and certain PRE herbicides. Dissertation, North Carolina State University, Raleigh, USA, 116 pp.

Bugg R.L., McGourty G., Sarrantonio M., Lanini W.T., Bartolucci R. 1996. Comparison of 32 cover crops in an organic vineyard on the north coast of California. Biol. Agric. Hortic. 13: 63-81.

Burhard N., Lynch D., Percival D., Sharifi M. 2009. Organic mulch impact on vegetation dynamics and productivity of highbush blueberry under organic production. HortScience 44 (3): 688-696.

Burrows R.L., Pfleger F.L. 2002. Arbuscular mycorrhizal fungi respond to increasing plant diversity. Can. J. Bot. 80 (2): 120-130.

Byers R.E. 1984. Control and management of vertebrate pests in deciduous orchards of the eastern United States. Hortic. Rev. 6: 253-285.

Caldwell C.J., Hynes R.K., Boyetchko S.M., Korber D.R. 2012. Colonization and bioherbicidal activity on green foxtail by Pseudomonas fluorescens BRG100 in a pesta formulation. Can. J. Microbiol. 58 (1): 1-9.

Camposeo S., Vivaldi G.A. 2011. Short-term effects of of de-oiled pomace mulching on a young super high density olive orchard. Sci. Hortic. 129 (4): 613-621. DOI: 10.1016/j.scienta.2011.04.034.

Caroll J., Pritts M.P., Heidenreisch C. 2012. Production Guide for Organic Blueberries. New York State Integrated Pest Management Publication 225, Cornell University, New York, $49 \mathrm{pp}$.

Cianciara T. 1987. Określenie skuteczności preparatu Ronstar w zwalczaniu powoju na plantacji porzeczek. [Evaluation of efficiency Ronstar herbicide to control bindweed (Convolvolus arvensis) on the black currant plantation]. p. 13-16. In: Proc. of the IX Meeting of Herbicide Group, Committee of Horticultural Science, Polish Academy of Sciences, Lublin, Poland, 10 June 1987, 78 pp.

Christians N.E. 1995. A natural herbicide from corn meal for weed-free lawns. IPM Practitioner 17 (10): 5-6.

Cloutier D.C., Lamarre M. 1997. Weed control and winter protection of strawberries in Quebec using interseeded crops. Acta Hortic. 439: 893-898.

Cockroft B., Wallbrink J.C. 1996. Root distribution of orchard trees. Aust. J. Agr. Res. 17 (1): 49-54.

Conticello L., Gandullo R. 1991. Survey of summer weeds in the upper valley of Rio Negro y Neuquen. p. 19-26. In: Proc. 12th Argentine Meeting on Weeds and their Control, Mar del Plata, Argentina, 9-11 October 1991.

Cox J.A., Morris S., Dalby T. 2014. Woodchip or weedmat? A comparative study on the effects of mulch on soil properties and blueberry yield. Acta Hortic. 1018: 369-374.

Czynczyk A., Bielicki P., Mika A., Krawiec A. 2011. A nine-year evaluation of several scab-resistant apple cultivars for organic fruit production. J. Fruit Ornam. Plant Res. 19 (2): 87-97.

Dale A. 2000. Black plastic mulch and between-row cultivation increase black currant yields. HortTechnology 10 (2): 307-308.

Dayan F.E., Cantrell C.I., Duke O.S. 2009. Natural products in crop protection. Bioorg. Medic. Chem. 17 (12): 4022-4034.

den Hollander N.G, Bastiaans L., Kropff M.J. 2007. Clover as a cover crop for weed suppression in an intercropping design. I. Characteristics of several clover species. Eur. J. Agron. 26 (2): 92-103.

Dilley C.A., Nonnecke G.R., Christians N.E. 1999. Strawberry growth and weed control in response to using corn gluten hydrolysate. HortScience 34 (3): 473.

Dittmar P.J., Williamson J.G. 2013. Weed management in blueberry. University of Florida, Institute of Food and Agricultural Sciences (IFAS) Extension Service. http://www.edis.ifas.ufl. edu/pdffiles/WG01600.pdf. [Accessed: March 18, 2014].

Doran J.W., Elliott E.T., Paustian K. 1998. Soil microbial activity, nitrogen cycling, and long-term changes in organic carbon pools as related to fallow tillage management. Soil Till. Res. 49 (1-2): 3-18.

Forcella F., Poppe S.R., Hansen N.C., Head W.A., Hoover E., Propsom F., McKensie J. 2003. Biological mulches for managing weeds in transplanted strawberry (Fragaria xananassa). Weed Technol. 17 (4): 782-787.

Futch S.H. 2000. Weed control in Florida. p. 55. In: Abstracts of Third International Weed Science Congress, Foz do Iguassu, Brazil, 6-11 June 2000, 301 pp.

Giesey J.P., Dobson S., Solomon K.R. 2000. Ecotoxicological risk assessment for Roundup herbicide. Rev. Environ. Contam. Toxicol. 167: 35-120.

Granatstein D., Mullinix K. 2008. Mulching options for northwest organic andconventional orchards. HortScience 43 (1): 45-50.

Granatstein D., Sanchez E. 2009. Research knowledge and needs for orchard floor management in organic tree fruit systems. Int. J. Fruit Sci. 9 (3): 257-281.

DOI: $10.1080 / 15538360903245212$.

Graupner P.R., Gerwick B.C., Siddall T.L. 2006. Chlorosis inducing phytotoxic metabolites: new herbicides from Phoma macrostoma. p. 37-47. In: “Natural Products for Pest Management" (A.M. Rimando, S.O. Duke, eds.). American Chemical Society Symposium Series No. 927, Washington, DC, USA, 319 pp.

Gut D., Barben E., Riesen W. 1996. Critical period for weed competition in apple orchards: preliminary results. Acta Hortic. $422: 273-277$.

Hallett S.G. 2005. Where are the bioherbicides? Weed Sci. 53 (3): 404-415.

Harrington K.C., Hartley M.J., Rahman A., James T.K. 2002. Strategies for controlling weeds in New Zealand apple orchard. p. 208-211. In: Proc. 13th Australian Weeds Conference, Perth, Australia, 8-13 September 2002, 764 pp. 
Harrington K.C., Hartley M.J., Rahman A., James T.K. 2005. Long term ground cover options for apple orchards. New Zealand Plant Prot. 58: 164-168.

Hartley M.J., Rahman A., Harrington K.C., James T.K. 2000. Assessing ground covers in a newly planted apple orchard. New Zealand Plant Prot. 53: 22-27.

Heinonen-Tanski H., Rosenberg C., Siltanen H., Kilpi S., Simojoki P. 1985. The effect of the annual use of pesticides on soil microorganisms, pesticide residues in the soil and barley yields. Pest Sci. 16 (4): 341-348.

Hoagland L., Carpenter-Boggs L., Granatstein D., Mazzola M., Smith J., Peryea F., Reganold J.P. 2008. Orchard floor management effects on nitrogen fertility and soil biological activity in a newly established organic apple orchard. Biol. Fert. Soils 45 (1): 11-18.

Humphries D., Byrtus G., Anderson A.M. 2005. Glyphosate Residues in Alberta's Atmospheric Deposition, Soils and Surface Waters. Information Centre Alberta Environment, Edmonton, Canada, 51 pp.

Horton D.R., Broers D.A., Lewis R.R., Granatstein D., Zack R.S., Unruh T.R., Moldenke A.R., Brown J.J. 2003. Effects of mowing frequency on densities of natural enemies in three Pacific Northwest pear orchards. Entomol. Exp. Appl. 106 (2): 135-145.

Johnson M.S., Fennimore S.A. 2005. Weed and crop response to colored plastic mulches in strawberry production. HortScience 40 (5): 1371-1375.

Jones A.L., Sutton T.B. 1996. Diseases of Tree Fruits in the East. Michigan State University Bull. NCR 45, 95 pp.

Jung J.S., Lee J.S., Choi C.D. 1997. Weed occurrence in apple orchards in Korea. Korean J. Weed Sci. 17 (2): 147-156.

Kelly M.J., Pritts M.P., Bellinder R.R. 2007. Evaluation of new cultivation tools to reduce labor requirements in matted-row strawberry culture. HortTechnology 17 (1): 87-94.

Kennedy A.C., Smith K.L. 1995. Soil microbiological diversity and the sustainability of agricultural soils. Plant Soil 170 (1): 75-86.

Kęsik T., Maskalaniec T. 2004. The effect of soil mulching on weed infestation in a strawberry plantation. Latvian J. Agron. 7: 209-213.

Kosterna E. 2014. The effect of soil mulching with organic mulches, on weed infestation in broccoli and tomato cultivated under polypropylene fibre, and without a cover. J. Plant Prot. Res. 54 (2): 188-198.

Kwiatkowska J. 2007. Ocena możliwości wykorzystania węgla brunatnego jako efektywnego źródła materii organicznej $\mathrm{w}$ gruntach przekształconych antropogenicznie. [Evaluation of brown coal as an effective source of organic matter in anthropologically transformed soils]. Inżynieria i Ochrona Środowiska 10 (1): 71-85.

Lamb D.C., Kelly D.E., Hanley S.Z., Mehmood Z., Kelly S.L. 1998. Glyphosate is an inhibitor of plant cytochrome P450: functional expression of Thlaspi arvensae cytochrome P45071B1/ reductase fusion protein in Escherichia coli. Biochem. Biophys. Res. Commun. 244 (1): 110-114.

Larsson L. 1997. Evaluation of mulching organically grown black currant, (Ribes nigrum) in terms of its effects on the crop and the environment. Ph.D. thesis, Swedish University of Agricultural Sciences, Department of Horticulture, Alnarp, Sweden. Acta Universitatis Agriculturae Suecicae, s. Agraria, 28, 18 pp.
Lawson H.M., Wiseman J.S. 1976a. Weed competition in springplanted raspberries. Weed Res. 16 (3): 155-162.

Lawson H.M., Wiseman J.S. 1976b. Weed competition in springplanted strawberries. Weed Res. 16 (5): 345-354.

Lehnert R. 2012. Selecting herbicides for tree fruit. Good Fruit Grower 63 (8): 32-33.

Lindhard Pedersen H. 2002. Covercrops in black currant (Ribes nigrum). Acta Hortic. 585: 633-638.

Lipecki J. 2004. Weeds in orchards in Lublin region (almost) twenty years later - preliminary report. J. Fruit Ornam. Plant Res. 12: 105-111.

Lipecki J. 2006. Weeds in orchards - pros and contras. J. Fruit Ornam. Plant Res. 14 (3): 13-18.

Lisek J. 2003. Possibilities for effective control of Convolvulus arvensis with bentazon in black currant. IOBC/WPRS Bull. 26 (2): 193-195.

Lisek J. 2005. The response of black currant and weeds to glyphosate. Folia Hortic. 17 (2): 71-79.

Lisek J. 2010. Wpływ terminu usuwania chwastów na wzrost i plonowanie nowo sadzonych truskawek. [Growth and yielding of newly planted strawberries after different time of weeding]. Prog. Plant Prot./Post. Ochr. Roślin 50 (2): 815-819.

Lisek J. 2012a. Skuteczność zwalczania wierzbownicy gruczołowatej (Epilobium adenocaulon) i innych chwastów przez glifosat i MCPA stosowanych z adiuwantem AS 500 SL w sadzie jabłoniowym. [Willow herb and other weeds response to glyphosate and MCPA applied with adjuvant AS 500 SL in apple orchard]. Zesz. Nauk. Inst. Sadow. Kwiac. 20: $12-20$.

Lisek J. 2012b. Synanthropic flora of strawberry plantations and their surroundings. Veg. Crops Res. Bull. 77: 113-127.

Lisek J. 2012c. Synanthropic orchard flora in West Mazovia - central Poland. J. Fruit Ornam. Plant Res. 20 (2): 71-83.

Lisek J. 2014. Chwasty. [Weeds]. p. 185-204. In: „Program ochrony roślin sadowniczych". [“Programme of Fruit Crops Protection”] (Z. Płuciennik, A. Broniarek-Niemiec, S. Masny, J. Lisek, B. Łabanowska, P. Sobiczewski, eds.). Hortpress, Warszawa, Poland, 208 pp.

Lisek J., Habdas H., Gawroński S.W. 2002. Relationship between selected morphological, anatomical and cytological characteristics of leaves and the level of tolerance to herbicides in strawberry cultivars. Acta Physiol. Plant. 24 (4): 371-378.

Łęski R. (ed.). 1983. Szkodniki i choroby roślin sadowniczych. [Pests and Diseases of Fruit Crops]. Państwowe Wydawnictwo Rolnicze i Leśne, Warszawa, Poland, 468 pp.

Mage F. 1982. Black plastic mulching compared to other orchard soil management methods. Sci. Hortic. 16 (2): 131-136.

Markuszewski B., Kopytowski J. 2008. Zachwaszczenie i koszty jego regulowania w sadzie jabłoniowym z produkcja integrowana. [Weed infestation and costs of their regulation in apple orchard with IPM]. Zesz. Nauk. Inst. Sadow. Kwiac. 16: 35-50.

Mercik S., Smolarz K. 1995. Influence of fertilization and mulching on the growth, fruiting and chemical composition of soil and leaves of highbush blueberry. Acta Hortic. 383: 323-329.

Merwin I.A. 2003. Orchard Floor Management Systems. p. 303-318. In: "Apples: Botany, Production and Uses" (D.C. Ferree, I. Warrington, eds.). CABI Publ., Wallingford, UK, 660 pp. 
Merwin I.A., Ray J.A., Curtis P.D. 1999. Orchard groundcover management systems affect meadow vole populations and damage to apple trees. HortScience 34 (2): 271-274.

Merwin I.A., Rosenberger D.A., Engle C.A., Rist D.L., Fargione M. 1995. Comparing mulches, herbicides, and cultivation as orchard groundcover management systems. HortTechnology 5 (2): 151-158.

Merwin I.A., Stiles W.C. 1994. Orchard ground cover management impacts on apple tree growth and yield, and nutrient availability and uptake. J. Amer. Soc. Hort. Sci. 119 (2): 209-215.

Merwin I.A., Stiles W.C., van Es H.M. 1994. Orchard groundcover management impacts on soil physical properties. J. Amer. Soc. Hort. Sci. 119 (2): 216-222.

Merwin I.A., Wilcox W.F., Stiles W.C. 1992. Influence of orchard ground cover management on the development of Phytophthora crown and root rots of apple. Plant Dis. 76 (2): 199-205.

Mika A. 2004. The importance of biodiversity in natural environment and in fruit plantations. J. Fruit Ornam. Plant Res. 12 (Special ed.): 11-21.

Mika A., Krzewińska D., Olszewski T. 1998. Effect of mulches, herbicides and cultivation as orchard groundcover management systems in young apple tree orchard. J. Fruit Ornam. Plant Res. 6 (1): 1-13.

Neilsen G.H., Hogue E.J. 1985. Effect of orchard soil management on the growth and leaf nutrient concentration of young dwarf 'Red Delicious' apple trees. Can. J. Soil Sci. 65 (2): 309-315.

Neilsen G.H., Hogue E.J. 2000. Comparison of white clover and mixed sodgrass as orchard floor vegetation. Can. J. Plant Sci. 80 (3): 617-622.

Neumann G., Kohls S., Landsberg E., Stock-Oliveira Souza K., Yamada T., Röhmheld V. 2006. Relevance of glyphosate transfer to non target plants via the rhizosphere. J. Plant Dis. Prot. 20: 963-969.

Niggli U., Weibel F.P., Gut W. 1990. Weed control with organic mulch materials in orchards. Results from 8 year field experiments. Acta Hortic. 285: 97-102.

Nonnecke G.R., Christians N.E. 1997. Strawberry production using corn gluten meal as a natural nitrogen source and weed control product. Acta Hortic. 439: 725-730.

Novo R.J., Nobile R.A., Zaninetti M.R. 2000. Weeds in peach tree crops in Cordoba. Hort. Argen. 18 (44/45): 43-50.

Parker M.L., Hull J., Perry R.L. 1993. Orchard floor management affects peach rooting. J. Amer. Soc. Hort. Sci. 118 (6): 714-718.

Patton A., Weisenberger D. 2012. Efficacy of current organic postemergent weed control options in turfgrass systems. p. 26-30. In: 2011 Annual Report - Purdue Univ. Turfgrass Sci. Progr., West Lafayette, Indiana, USA, 83 pp.

Peachey E., Boydston R., Hanson B., Miller T., Al-Khatib K. 2013. Preventing and managing glyphosate-resistant weeds in orchards and vineyards. ANR Publication 8501, University of California, Agriculture and Natural Resources. http://anrcatalog.ucanr.edu [Accessed: August 12, 2014].

Pritts M.P., Kelly M.J. 2001. Early season weed competition reduces yield of newly planted matted row strawberries. HortScience 36 (4): 729-731.

Pritts M.P., Kelly M.J. 2004. Weed competition in a mature matted row strawberry planting. HortScience 39 (5): 1050-1052.
Quarles W. 2010. Alternative herbicides in turfgrass and organic agriculture. Integrated Pest Management Practitioner 32 (5/6): $1-8$.

Rabcewicz J., Białkowski P. 2011. Ocena skuteczności mechanicznego niszczenia chwastów w ekologicznej uprawie jabłoni. [The efficiency of mechanical weed control in ecological apple production]. J. Res. Appl. Agric. Eng. 56 (4): 79-83.

Richard S., Moslemi S., Sipahutar H., Benachour N., Seralini G.E. 2005. Differential effects of glyphosate and Roundup on human placental cells and aromatase. Environ. Health Perspect. 113 (6): 716-720. DOI: 10.1289/ehp.7728.

Rieux R., Simon S., Defrance H. 1999. Role of hedgerows and ground cover management on arthropod populations in pear orchards. Agric. Ecosyst. Environ. 73 (2): 119-127.

Rifai M.N., Astatkie T., Lacko-Bartosova M., Gadus J. 2002. Effect of two different thermal units and three types of mulch on weeds in apple orchards. J. Environ. Eng. Sci. 1 (5): 1-16.

Rowley M.A., Ransom C.V., Reeve J.R., Black B.L. 2011. Mulch and organic herbicide combinations for in-row orchard weed suppression. Int. J. Fruit Sci. 11 (4): 316-331. DOI: 10.1080/15538362.2011.630295.

Roy D.N., Konar S.K., Banerjee S., Charles D.A., Thompson D.G., Prasad R.P. 1989. Uptake and persistence of the herbicide glyphosate vision in fruit of wild blueberry and red raspberry. Can. J. Forest Res. 19 (7): 842-847. DOI: 10.1139/x89-128.

Rozpara E., Grzyb Z.S., Bielicki P. 2008. Influence of various soil maintenance methods in organic on the growth and yielding of sweet cherry trees in the first years after planting. J. Fruit Ornam. Plant Res. 16: 17-24.

Sanchez J.E., Edson Ch.E., Bird G.W., Whalon M.E., Willson T.C., Harwood R.R., Kizilkaya K., Nugent J.E., Klein W., Middleton A., Loudon T.L., Mutch D.R., Scrimger J. 2003. Orchard floor and nitrogen management influences soil and water quality and tart cherry yields. J. Amer. Soc. Hort. Sci. 128 (2): 277-284.

Sas-Paszt. L., Pruski K., Żurawicz E., Sumorok B., Derkowska E., Głuszek S. 2014. The effect of organic mulches and mycorrhizal substrate on growth, field and quality of Gold Milenium apple on M.9 rootstock. Can. J. Plant Sci. 94 (2): 281-289. DOI: 10.4141/cjps2012-239.

Schonbrunn E., Eschenburg S., Shuttleworth W.A., Schloss J.W., Amrhein N., Evans J.N., Kabsch W. 2001. Interaction of the herbicide glyphosate with its target enzyme 5-enolpyruvylshikimate 3-phosphate synthase in atomic detail. Proc. Natl. Acad. Sci. USA 98 (4): 1376-1380.

Shribbs J.M., Skroch W.A. 1986a. Influence of 12 ground cover systems on young 'Smoothee Golden Delicious' apple trees: I. Growth. J. Amer. Soc. Hort. Sci. 111 (4): 525-528.

Shribbs J.M., Skroch W.A. 1986b. Influence of 12 ground cover systems on young 'Smoothee Golden Delicious' apple trees: II. Nutrition. J. Amer. Soc. Hort. Sci. 111 (4): 529-533.

Sosna I., Licznar-Małańczuk M., Czaplicka M. 2009. Wstępna ocena wpływu żywych ściółek na wzrost i owocowanie drzew jabłoni i gruszy. [The influence of living mulches on the growth and fruiting of pear and apple trees - preliminary results]. Zesz. Probl. Post. Nauk Rol. 536: 197-203.

Spiers J.M. 1986. Root distribution of 'Tifblue'rabbiteye blueberry as influenced by irrigation, incorporated peatmoss, and mulch. J. Amer. Soc. Hort. Sci. 111: 877-880.

Stefanelli D., Zoppolo R.J., Perry R.L., Weibel F. 2009. Organic orchard floor management systems for apple effect on 
rootstock performance in the Midwestern United States. HortScience 44 (2): 263-267.

Storkey J., Westbury D.B. 2007. Managing arable weeds for biodiversity. Pest Manag. Sci. 63 (6): 517-523.

Szewczuk A., Gudarowska E. 2004. The effect of different types of mulching on yield, size, color, and storability of 'Jonagored' apples. J. Fruit Ornam. Plant Res. 12 (Special ed.): 207-214.

Szewczuk A., Gudarowska E. 2006. Performance of young peach trees planted in ridges and mulched in tree rows. J. Fruit Ornam. Plant Res. 14: 135-141.

Tasseva V. 2005. Species composition of weed vegetation in different apple growing technologies. Not. Bot. Hort. Agrobot. Cluj Napoca 33: 58-63.

TerAvest D., Smith J.L., Carpenter-Boggs L., Hoagland L., Granatstein D., Reganold J.P. 2010. Influence of orchard floor management and compost application timing on nitrogen partitioning in apple trees. HortScience 45 (4): 637-642.

Treder W., Klamkowski K., Mika A., Wójcik P. 2004. Response of young apple trees to different orchard floor management system. J. Fruit Ornam. Plant Res. 12: 113-123.

Trinka D.L., Pritts M.P. 1992. Micropropagated raspberry plant establishment responds to weed control practice, row cover use, and fertilizer placement. J. Amer. Soc. Hort. Sci. 117 (6): 874-880.

Tworkoski T.J. 2000. Response of potted peach trees to pruning and grass competition. HortScience 35 (7): 1209-1212.

Tworkoski T.J., Glenn D.M. 2001. Yield, shoot and root growth, and physiological responses of mature peach trees to grass competition. HortScience 36 (7): 1214-1218.

Tworkoski T.J., Glenn D.M., Welker W.V. 1997. Carbohydrate and nitrogen partitioning within one-year shoots of young peach trees grown with grass competition. HortScience 32 (7): 1174-1177.

Tworkoski T., Miller S. 2001. Apple and peach orchard establishment following multi-year use of diuron, simazine, and terbacil. HortScience 36 (7): 1211-1213.

Tworkoski T.J., Welker W.V. 1996. Effect of twelve annual applications of diuron, simazine, and terbacil on a soil microbe community in West Virginia. p. 2-6. In: Proc. 15th Annual Meeting of the Northeastern Weed Science Society, Williamsburg, Virginia, USA, 2-5 January 1996.

Ustuner T., Ustuner M. 2011. Investigation on different mulch materials and chemical control for controlling weeds in apple orchard in Turkey. Sci. Res. Ess. 6 (19): 3979-3985.
Varga C., Buban T., Piskolczi M. 2004. Effect of organic mulching on the quantity of microorganisms in soil of apple plantation. J. Fruit Ornam. Plant Res. 12: 147-155.

Walsh B.D., Salmins S., Buszard D.J., MacKenzie A.F. 1996. Impact of soil management systems on organic dwarf apple orchards and soil aggregate stability, bulk density, temperature and water content. Can. J. Soil Sci. 76 (2): 203-209.

Weber C.A. 2003. Biodegradable mulch films for weed suppression in the establishment year of matted-row strawberries. HortTechnology 13 (4): 665-668.

WeedScience 2014. Weeds resistant to glycines (G/9) by species and country. www.weedscience.org. [Accessed: April 23, 2014].

Wehtje G., Altland J.A., Gilliam C.H. 2009. Interaction of glyphosate and pelargonic acid in ready-to-use weed control products. Weed Technol. 23 (4): 544-549. DOI: 10.1614/WT-08-044.1.

Weibel F. 2002. Soil management and in-row weed control in organic apple production. Compact Fruit Tree 35: 118-121.

Wiman M.R., Kirby E.M., Granatstein D.M., Sulllivan T.P. 2009. Cover crops influence meadow vole presence in organic orchards. HortTechnology 19 (3): 558-562.

Wróbel M. 1999. Orchard flora in Szczecin surroundings. J. Fruit Ornam. Plant Res. 7 (3): 133-145.

Wyss E. 1996. The effects of artificial weed strip on diversity and abundance of the arthropod fauna in Swiss experimental apple orchard. Agric. Ecosyst. Environ. 60 (1): 47-59.

Yao S., Merwin I.A., Bird G.W. Abawi G.S., Thies J.E. 2005. Orchard floor management practices that maintain vegetative or biomass groundcover stimulate soil microbial activity and alter soil microbial community composition. Plant Soil 271 (1-2): 377-389.

Yu J., Morishita D.W. 2014. Response of seven weed species to corn gluten meal and white mustard (Sinapis alba) seed meal rates. Weed Technol. 28 (1): 259-265. DOI: 10.1614/ WT-D-13-00116.1.

Zebarth B.J., Freyman S., Kowalenko C.G. 1993. Effect of ground covers and tillage between raspberry rows on selected soil physical and chemical parameters and crop response. Can. J. Soil Sci. 73: 481-488.

Zimdahl R.L. 1980. Weed - Crop Competition. A review. Publ. International Plant Protection Center, Oregon State University, Corvallis, USA, $196 \mathrm{pp}$.

Zobiole L.H.S., Oliveira Jr.R.S., Kremer R.J., Muniz A.S., Oliveira Jr. A. 2010. Nutrient accumulation and photosynthesis in glyphosate-resistant soybeans is reduced under glyphosate use. J. Plant Nutr. 33 (12): 1860-1873. DOI: 10.1080/01904167.2010.491890. 